\title{
Improvement of PV/T Based Reverse Osmosis Desalination Plant Performances Using Fuzzy Logic Controller
}

\author{
Mahmoud Ammous ${ }^{1}$, Sana Charfi' ${ }^{1}$, Ahmad Harb ${ }^{2}$, Maher Chaabene ${ }^{1}$ \\ ${ }^{1}$ University of Sfax, Sfax, Tunisia \\ ${ }^{2}$ School of Natural Resources Engineering and Management, German Jordanian University, Amman, Jordan \\ Email:mahmoud@cmerp.net,charfisana@yahoo.fr, Ahmad.Harb@gju.edu.jo,maherchaabene@gmail.com
}

Received 23 December 2015; accepted 28 February 2016; published 2 March 2016

Copyright (C) 2016 by authors and Scientific Research Publishing Inc.

This work is licensed under the Creative Commons Attribution-NonCommercial International License (CC

BY-NC).

http://creativecommons.org/licenses/by-nc/4.0/

(c) () (9) Open Access

\begin{abstract}
Photovoltaic based reverse osmosis desalination systems (PV/RO) present an effective method of water desalination especially in remote areas. The increase of the feed water temperature leads to an amelioration of the plant performances. Photovoltaic Thermal Collector (PV/T) represents an ideal power source as it provides both electric and thermal energies for the reverse osmosis process. Nevertheless, PV/T based RO plants should be controlled in order to solve operation problems related to electrical efficiency, reverse osmosis membrane, produced water and the rejected salts. This paper suggests a fuzzy logic controller for the flow rate of the circulating fluid into the PV/T collectors so as to ameliorate the system performances. The designed controller has improved the PV/T field electrical efficiency and preserved the reverse osmosis membrane which upgrades the system productivity. LABVIEW software is used to simulate the controlled system and validate the effectiveness of the controller.
\end{abstract}

\section{Keywords}

PV/T Collector, Reverse Osmosis, Control, Fuzzy Logic Controller

\section{Introduction}

Electric energy and fresh water supply present the major challenge in many parts of the world [1]. Fresh water demand for drinking, irrigation, industrial use, and household has doubled. Desalination of seawater and brackish water may solve water deficiency all over the world [2]. In addition, the energetic deficit and the environmental pollution from conventional energy resources (fossil fuels) promote the use of renewable energy for wa-

How to cite this paper: Ammous, M., Charfi, S., Harb, A. and Chaabene, M. (2016) Improvement of PV/T Based Reverse Osmosis Desalination Plant Performances Using Fuzzy Logic Controller. International Journal of Modern Nonlinear Theory and Application, 5, 11-27. http://dx.doi.org/10.4236/ijmnta.2016.51002 
ter desalination. Hence, desalination systems supplied by renewable energy resources are widely discussed in literature [3]. The choice of the appropriate desalination system depends essentially on the plant size, the exploited renewable energy resource, and the salinity of feed water. It is concluded that photovoltaic based solar energy is used with thermal desalination processes to cover the required thermal energy. In this case, desalination processes involve phase change such as the Multi Stage Flash (MSF) and the Multi Effect Distillation (MED) [4] [5]. Moreover, solar energy is exploited to produce electrical energy while the process is membrane (Reverse Osmosis) or hybrid such as Membrane Distillation (MD) [6].

Reverse osmosis (RO) is considered as the most used desalination process due to its high recovery ratio and low energy consumption [7]. Several researches focused on modeling Reverse Osmosis process in order to identify the process performance, and the energy consumption for the considered desalination process [8]. Researchers evince that photovoltaic energy performs well when used for reverse osmosis desalination [9].

Many studies show feed water temperature impacts on RO process recovery ratio, the consumed energy per cubic meter and the quantity of salt rejection [10]. Simulations and experiments show an improvement in RO process recovery ratio when feed water temperature increases [11] [12]. Therefore, reverse osmosis desalination plants are controlled especially when the improvement of feed water temperature is reachable [13].

Photovoltaic thermal technology (PV/T) is a hybrid system which combines the functions of solar thermal collector and photovoltaic (PV) panel. As it provides heat production, fluid circulation in the back of PV/T panel improves electrical efficiency of PV cells [14]. As for the PV/T produced thermal energy is used to heat seawater so as to increase the efficiency of (RO) desalination process [15]. Different PV/T configurations and plants are studied and modeled [16]. PV/T modeling aims essentially to quantify the produced electric and thermal energies. Additionally, the dynamic modeling evaluates temperature changes for each PV/T system segment (glass cover, photovoltaic cells, absorber plate, coolant fluid...). As well, sizing strategies are developed for PV/T based plants [17] [18]. System analysis exhibits an improvement of PV cells efficiency compared to conventional photovoltaic panels [19]. In fact, the control of PV/T systems is based on varying the circulated fluid flow rate [20] [21]. This variation allows the control of electric and thermal efficiencies of the PV/T collector. Indeed, the control balances between thermal and electrical productions in order to favor the production of one of these two energy forms [22].

Several researchers studied control of solar powered reverse osmosis systems. Control for reverse osmosis desalination serves to guarantee good quality of the produced water (acceptable salinity) and to protect the RO membrane. In several cases, the control is an energy management optimization which purposes to reduce the consumed energy by the desalination process and to amplify water production. Therefore, techniques such as Dynamic Matrix Programming, PID, Model Predictive Control and Fault Tolerant were applied [23]-[26]. Additionally, Fuzzy Logic Controller (FLC) is used extensively in industrial applications due to its simplicity as a process to control system, and its low cost [27] [28]. Fuzzy logic controller (FLC) presents a rule-based controller where the control action depends on a defined set of rules, and on the considered input variables. It consists of a control algorithm based on a linguistic control strategy. The consequent results from a linear input-output relation in a region of the state space. Recently, considerable development in (FLC) theory was shown. Therefore, over the past few decades, Fuzzy Control is being utilized in various domains. It is used successfully and extensively to control solar based systems: with conventional solar thermal plants to maximize heat production [29], and with photovoltaic based plants for an energy management [30].

Moreover, the economic aspect is very important especially for renewable energy based systems. In fact, the economic analysis presents a significant clue to valorize the exploitation of renewable energy resources [31]. For water desalination, the economic analysis is habitually to compare water production cost of renewable energy based systems and traditional desalination systems [32].

In this paper, the FLC is used to control a PV/T based reverse osmosis desalination system. Thermal and electric productions are both controlled in order to optimize the PV/T field productivity. In addition, the used FLC aims to ameliorate the RO unit recovery and also to protect the RO membrane from an overheating. Fuzzy Logic Controller is utilized to control the fluid flow rate in order to improve the system performances. The implemented FLC balances between the improvement of the PV/T field electrical efficiency and the RO unit recovery ratio. The paper will start with a modeling part where each system block is modeled; then the implemented FLC is identified; the final section is reserved to discuss the obtained results concerning the energetic and the economic gains. 


\section{Plant Modeling}

\subsection{Plant Description}

The considered plant is shown in Figure 1. A coolant fluid circulates into PV/T tubes and transfers the absorbed heat to the exchanger (1). The produced thermal energy is used to heat pumped water stored in the boiler (2). The coolant fluid serves also to reduce photovoltaic cells temperature in order to ameliorate the electrical efficiency of the PV/T field (3). RO unit (4) is supplied by water from the boiler (2) and by electrical energy by the $\mathrm{PV} / \mathrm{T}$ electrical generation. Heated pumped water will be transferred to the RO unit where the desalination stage is accomplished. Fluid flow rate is varied by variable speed pump (5) according to PV cells temperature, and water temperature in the boiler which presents a main factor that impacts RO unit performance. Produced electrical energy is used to supply variable speed pump, feed water pump (6), and the high pressure pump of the RO unit.

\subsection{PV/T Module Modeling}

The most important components in the PV/T collector are the PV plate and the solar thermal absorber. PV/T panel modeling is based on heat transfer principle. The sheet and tube PV/T system used in the present study composed of a PV module, a thermal absorber, glazing, working fluid, tube, and insulation (Figure 2).

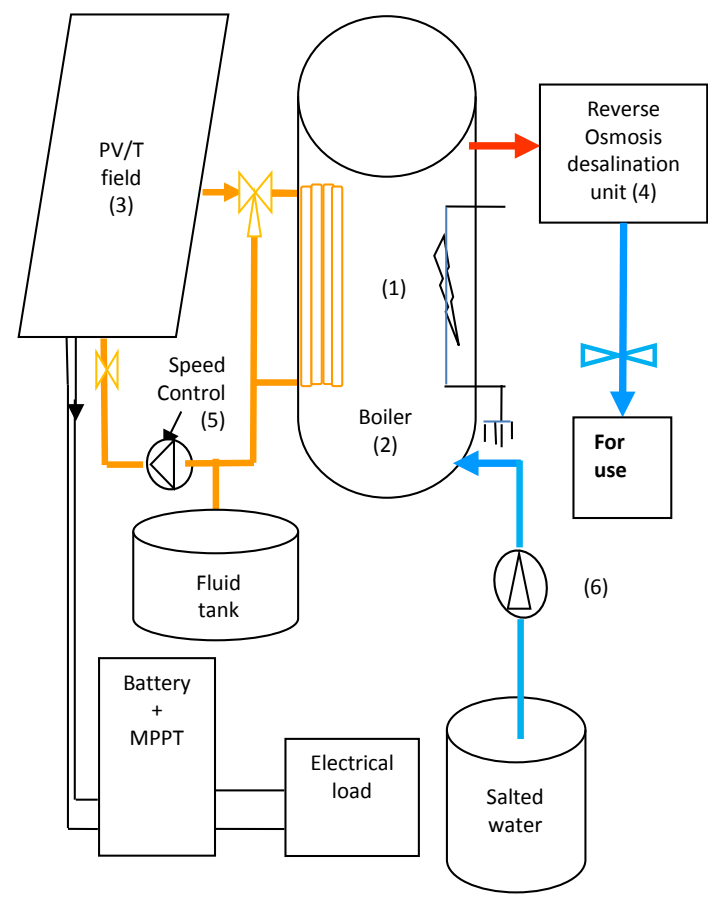

Figure 1. Schematic diagram of the desalination plant.

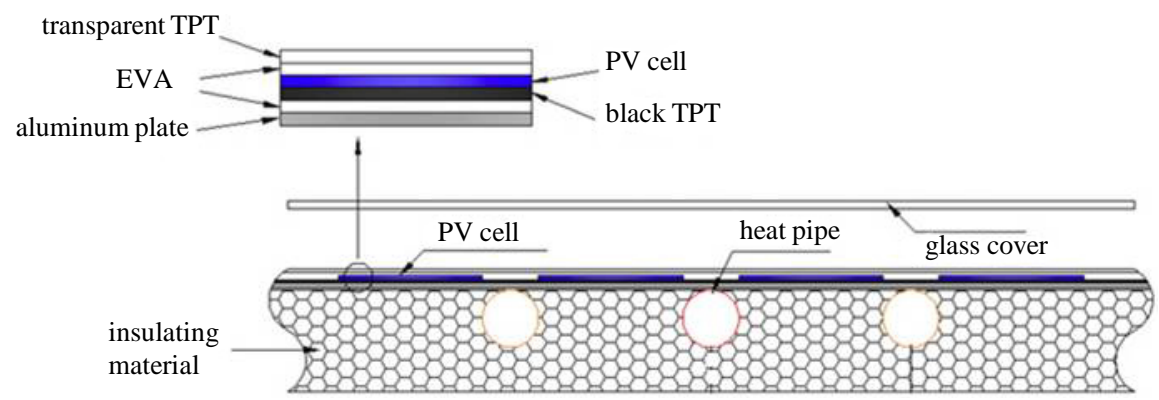

Figure 2. Sheet and tube configuration of a PV/T collector. 
System modeling is based on the energy balance equations developed by Chow [28]. The following assumptions are considered in the model development:

1) In all tubes sections, the mass flow rate of the working fluid is invariant.

2) The material properties of all PV/T system components are unchanged.

3) We compute the heat transfer coefficients in real time.

The temperature change of the glass cover $\left(T_{g}\right)$ is defined by [16]:

$$
M_{g} C_{g} \frac{\mathrm{d} T_{g}}{\mathrm{~d} t}=G \alpha_{g}+h_{\text {wind }} A_{a g}\left(T_{a}-T_{g}\right)+h_{g p} A_{g p}\left(T_{p}-T_{g}\right) .
$$

$M_{g}$ and $C_{g}$ are the mass and the specific heat coefficient of the glass cover respectively. $T$ presents the temperature, and the subscripts " $g$ ", " $a$ ", and " $p$ " present the glass cover, the ambient, and the PV plate respectively. $G$ presents the solar radiation $\left(\mathrm{W} / \mathrm{m}^{2}\right)$.

With $(A)$ is the PV/T collector area and [28]:

$$
A=A_{g p}=A_{a g} .
$$

The absorptance and the transmittance of the glass are defined respectively by:

$$
\begin{gathered}
\alpha_{g}=1-\tau_{a} \\
\tau_{a}=\exp \left[-A \delta_{g}\left(1-\frac{\sin ^{2} \theta_{i}}{R_{g}^{2}}\right)\right]^{-0.5}
\end{gathered}
$$

$\delta_{g}, R_{g}$, and $\theta_{i}$ are the refractive index, the thickness of the glass cover, and the incident angle respectively.

The convective heat transfer coefficient due to wind is given by:

$$
h_{\text {wind }}=3 u_{a}+2.8
$$

with $u_{a}$ is the wind velocity.

The heat transfer coefficient between glass cover and PV plate is expressed by:

$$
h_{g p}=\left(h_{r}\right)_{g p}+\left(h_{c}\right)_{g p} \frac{\sigma\left(\theta_{g}^{2}+\theta_{p}^{2}\right)\left(\theta_{g}+\theta_{p}\right)}{\frac{1}{\varepsilon_{g}}+\frac{1}{\varepsilon_{p}}-1}+\frac{N u_{a} k_{a}}{\delta_{a}}
$$

$\Theta, \varepsilon$, and $\sigma$ present the temperature $\left({ }^{\circ} \mathrm{K}\right)$, the emissivity, and the Stefan Boltzmann constant respectively.

The radiative heat transfer coefficient between the glass cover and the surroundings is defined by the following equation:

$$
h_{r, a g}=\varepsilon_{g} \delta\left(\theta_{g}^{2}+\theta_{p}^{2}\right)\left(\theta_{g}+\theta_{p}\right) .
$$

Hollands et al., 1976 determine the Nausselt number by the following equation:

$$
N u_{a}=1+1.44\left[1-\frac{1708}{R_{a} \delta_{a} \cos \theta}\right]^{*}\left\{1-\frac{1708[\sin (1.8 \theta)]^{1.6}}{R_{a} \delta_{a} \cos \theta}\right\}+\left[\left(\frac{R_{a} \delta_{a} \cos \theta}{5830}\right)^{1 / 3}-1\right]^{*}
$$

with:

$$
0<R_{a} \delta_{a} \leq 10^{5}
$$

where, the Rayleigh $\left(R_{a}\right)$ number defined as:

$$
R_{a}=\frac{g \beta_{a}\left(T_{p}-T_{g}\right) \delta_{a}^{3}}{\kappa_{a} v_{a}} .
$$

$\beta_{a}, g, \kappa_{a}$, and $v_{a}$, are the coefficient of thermal expansion, the gravitational constant, thermal diffusivity, and kinematic viscosity of air respectively. 
The temperature change of the PV plate is defined by [16]:

$$
M_{p} C_{p} \frac{\mathrm{d} T_{p}}{\mathrm{~d} t}=G \alpha_{p}-E+h_{g p} A_{g p}\left(T_{g}-T_{p}\right)+h_{c p} A_{c p}\left(T_{c}-T_{p}\right)+h_{p t} A_{p t}\left(T_{t}-T_{p}\right)
$$

with $E$ is the produced electric power and:

$$
A_{c p}=\left(1-\frac{D_{o}}{W}\right)
$$

$D_{o}$ and $W$ are the outer diameter of tubes and spacing tubes respectively.

The plate absorptance is calculated by the following relation:

$$
\alpha_{p}=\frac{\tau_{a} \tau_{p} \alpha_{p}}{1-\left(1-\alpha_{p}\right) r} .
$$

The conductive heat transfer coefficient between the collector and the PV plate is defined by:

$$
h_{c p}=\frac{k_{a d}}{\delta_{a d}}
$$

with:

$$
h_{p t} A_{p t}=\frac{\delta_{p} L}{\left(\frac{\chi_{p}}{2 \kappa_{p}}\right)+\left(\frac{\delta_{a d} \delta_{p}}{k_{a d} D_{o}}\right)} .
$$

$h_{p t}$ presents the conductive heat transfer coefficient between the PV plate and tubes. $k_{a d}$ and $\delta_{a d}$ are the thermal conductivity and the adhesive layer thickness, respectively. $k_{p}$ and $\delta_{p}$ are the thermal conductivity and the PV plate thickness respectively. $L$ is the length of the tube. " $\tau_{p}$ " and " $r$ " are the transmittance and the reflectance of the glass for diffuse radiation, respectively.

And:

$$
\chi_{p}=\frac{W}{4} .
$$

The electrical power produced by the PV/T module is calculated by the following expression:

$$
E=G p \eta_{\text {cell }}
$$

where " $p$ " is the ratio of the cell area to the collector area also known as the packing factor.

The PV cells efficiency is determined by:

$$
\eta_{\text {cell }}=\eta_{r}\left[1-\beta_{r}\left(T_{p}-T_{r}\right)\right]
$$

$\beta_{r}$ and $\eta_{r}$ present the temperature coefficient and the reference cell efficiency respectively.

The heat balance on the absorber plate is determined by the following equation:

$$
M_{c} C_{c} \frac{\mathrm{d} T_{c}}{\mathrm{~d} t}=h_{c p} A_{c p}\left(T_{p}-T_{c}\right)+h_{c t} A_{c t}\left(T_{t}-T_{c}\right)+h_{c i} A_{c i}\left(T_{i}-T_{c}\right) .
$$

The conductive heat transfer coefficient between the absorber plate and insulation is defined by:

$$
h_{c i}=\frac{2 k_{i}}{\delta_{i}} .
$$

$\delta$ and $k$ are thickness and thermal conductivity of the insulation layer respectively. The subscripts " $c$ ", " $t$ ", and "i" refer to the absorber plate, tubes, and the insulation, respectively.

The heat transfer coefficient between tubes and the absorber plate is defined by:

$$
h_{c t}=\frac{2 k_{c}}{\chi_{c}} \text {. }
$$


With:

$$
\begin{aligned}
& A_{c i}=A\left(\frac{W-D_{o}}{W}\right) \\
& \chi_{c}=\frac{W-D_{o}}{4} \\
& A_{c t}=\delta_{c} L .
\end{aligned}
$$

The energy balance equation for tubes is given by:

$$
M_{t} C_{t} \frac{\mathrm{d} T_{t}}{\mathrm{~d} t}=h_{c t} A_{c t}\left(T_{c}-T_{t}\right)+h_{i t} A_{i t}\left(T_{i}-T_{t}\right)+h_{t f} A_{t f}\left(T_{f}-T_{t}\right) .
$$

With:

$$
\begin{aligned}
A_{i t} & =\left(\frac{\pi}{2}+1\right) D_{o} L \\
A_{i f} & =\pi D_{i} L .
\end{aligned}
$$

The transferred energy to the circulated fluid is determined by:

$$
M_{f} C_{f} \frac{\mathrm{d} T_{f 1}}{\mathrm{~d} t}=h_{t f} A_{f f}\left(T_{t}-T_{f 1}\right)+\dot{m}_{f} C_{f}\left(T_{f o}-T_{f 2}\right) .
$$

$T_{f o}$ and $T_{f 2}$ are respectively fluid temperature inlet PV/T tubes and fluid temperature outlet PV/T tube. $h_{t f}$ is the heat transfer coefficient between tubes and the circulated fluid. The temperature of the circulated fluid into tubes is defined by:

$$
T_{f 1}=\frac{T_{f 2}+T_{f o}}{2} .
$$

For the insulation layer, it is considered that: $\delta_{i} \gg D_{o}$, and $h_{i t}=h_{c i} \cdot h_{f}$ presents the convective heat transfer coefficient.

$$
\begin{aligned}
\frac{1}{A_{t f} h_{t f}} & =\frac{1}{h_{f} \pi D_{i} L} \\
A_{t f} & =\pi D_{i} L
\end{aligned}
$$

$D_{i}$ is the inlet tube diameter.

The energy balance equation for the insulation is given by:

$$
M_{i} C_{i} \frac{\mathrm{d} T_{i}}{\mathrm{~d} t}=h_{c i} A_{c i}\left(T_{c}-T_{i}\right)+h_{i t} A_{i t}\left(T_{t}-T_{i}\right)+h_{a i} A\left(T_{a}-T_{i}\right) .
$$

With:

$$
A_{i t}=\left(\frac{\pi}{2}+1\right) D_{o} L
$$

\subsection{Exchanger and Boiler Modeling}

The transferred energy from the working fluid to pumped water by the exchanger is determined as follows [30]:

$$
Q_{s}=\dot{m} C_{w}\left(T_{t k, i}-T_{\text {pump }}\right)=\xi \dot{m} C_{f}\left(T_{f 2}-T_{f o}\right) .
$$

The subscripts "tk,i" and "pump" refer to water temperature inlet the boiler (outlet the exchanger) and pumped feed water, respectively.

Water temperature in the boiler is determined by: 


$$
M_{t k} C_{t k} \frac{\mathrm{d} T_{t k}}{\mathrm{~d} t}=\dot{m}_{w} N C_{w}\left(T_{t k, i}-T_{t k, o}\right)+h_{t k} A_{t k}\left(T_{a}-T_{t k}\right) .
$$

$M_{t k}, C_{t k}$, are the mass, and the specific heat coefficient of water in the boiler, respectively. $N, \dot{m}_{w}, h_{t k}$, and $A_{t k}$ are the tubes number of the PV/T collector, water mass flow rate, heat transfer coefficient of the boiler, and the boiler surface, respectively.

\subsection{Reverse Osmosis Unit Modeling}

Reverse osmosis presents an effective filtration process for water purification. In fact, the water enters the cartridge and under the applied pressure, water molecules pass the membrane while the other molecules are rejected with a portion of unfiltered water (Figure 3).

Reverse osmosis modeling aims to identify:

-Mass flow rate of the permeate.

-Permeate salinity.

-Consumed energy.

-Water recovery rate.

Reverse Osmosis modeling is based on the solution diffusion principle. The permeate flow rate $\left(M_{p}\left[\mathrm{~m}^{3} / \mathrm{s}\right]\right)$ is determined by the following relation [29]:

$$
\dot{M}_{p}=\left(J_{s}+J_{w}\right) S_{M}
$$

with $S_{M}$ is the membrane active area in $\left(\mathrm{m}^{2}\right)$.

Permeate mass flux through the membrane $\left(J_{w}\right)$ and the salt mass flux through the membrane $\left(J_{s}\right)$, are defined respectively by the following equations:

$$
\begin{aligned}
& J_{w}=A_{m} S(\Delta P-\Delta \pi) \\
& J_{s}=B S\left(c_{w}-c_{p}\right)
\end{aligned}
$$

$A_{m}, B$, and $S$ represents the membrane pure water permeability $\left(\mathrm{kg} \cdot \mathrm{m}^{-2} \cdot \mathrm{s}^{-1}\right)$, the membrane salts permeability $\left(\mathrm{kg} \cdot \mathrm{m}^{-2} \cdot \mathrm{s}^{-1}\right)$, and the RO membrane surface area $\left(\mathrm{m}^{2}\right)$ respectively.

The transmembrane pressure $(\Delta P)$ and the transmembrane osmotic pressure $(\Delta \pi)$ are expressed as follows:

$$
\Delta P=P_{f}-P_{p}-\frac{\Delta P_{d r o p}}{2} .
$$

$P_{f}$ and $P_{p}$ are the feed pressure, and the permeate pressure respectively.

$$
\Delta \pi=\frac{2 R T \rho}{M_{\mathrm{NaCl}}}\left(C_{w}-C_{p}\right) .
$$

The universal gases constant $(R)$ is equal to $8.314 \mathrm{~J} \cdot \mathrm{mol}^{-1} \cdot \mathrm{K}^{-1} \cdot \mathrm{T}, \rho$, and $M_{\mathrm{NaCl}}$ are water temperature, water density, and the molar mass of $\mathrm{NaCl}$ respectively.

The pressure drop along the membrane channel $\left(\Delta P_{d r o p}\right)$ is defined by:

$$
\Delta P_{\text {drop }}=\lambda\left(\frac{\dot{M}_{f}+\dot{M}_{c}}{2 \rho}\right)^{\alpha} \text {. }
$$

And,

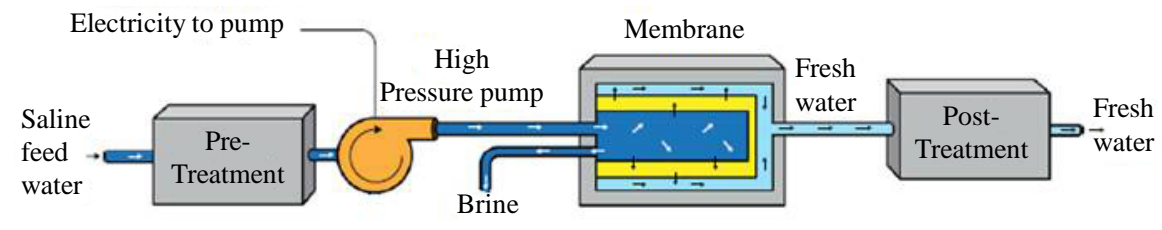

Figure 3. Schematic of Reverse Osmosis desalination process. 


$$
C_{w}-C_{p}=\left(\frac{C_{f}-C_{c}}{2}-C_{p}\right) e^{k r}
$$

$\dot{M}_{f}$ and $\dot{M}_{c}$ are the membrane feed flow rate, and the membrane concentrate flow rate respectively.

With: $\alpha=1.7$ and $\lambda=9.5 \times 10^{8}$.

The membrane water permeability $(A)$ is defined by the following relation:

$$
A=A_{\text {ref }} \cdot F F \cdot T C F \text {. }
$$

$A_{\text {ref }}$ presents the reference permeability at $T_{0}=298 \mathrm{~K}$ without fouling, TCF is the temperature correction factor, and $F F$ is the fouling factor. The influence of membrane fouling on membrane permeability is expressed by the fouling factor $F F$ which varies between $100 \%$ for new membranes and $80 \%$ for 4 years old membranes.

The temperature correction factor $(T C F)$ is defined as a function of feed water temperature. It is determined by the following relation [23]:

$$
\operatorname{TCF} \begin{cases}\exp \left(2640\left(\frac{1}{273+T_{w}}-\frac{1}{273}\right)\right) & \text { if } T_{w}<25^{\circ} \mathrm{C}, \\ \exp \left(3020\left(\frac{1}{273+T_{w}}-\frac{1}{273}\right)\right) & \text { if } T_{w}>25^{\circ} \mathrm{C}\end{cases}
$$

\section{Control Strategy}

\subsection{Control Objectives}

Even if the considered plant architecture can perform well, several operating problems can appear. In fact, Photovoltaic cells temperature impacts directly the electric efficiency of the PV/T field: the increase of Photovoltaic cells temperature decreases the PV/T field electrical efficiency. In addition, for a reverse osmosis desalination process, an overheat of feed water temperature destruct the reverse osmosis membrane. Therefore, the operating water temperature is limited by the manufacturer to $45^{\circ} \mathrm{C}$ [11]. Furthermore, the rejected salt quantity should be controlled as well as the produced desalinated water which should satisfy the need.

Hence, a Fuzzy Logic Controller based on controlling the flow rate of the circulated fluid into the PV/T panels is designed in order to ameliorate the system performances. The designed control system aims essentially to improve the PV/T electrical efficiency and preserve the reverse osmosis membrane. In addition, it aims to reduce the rejected salts quantity and, upgrade the system productivity.

\subsection{Fuzzy Logic Control}

Fuzzy Logic Control provides an effective manner to draw definite conclusions from imprecise information or vague ambiguous. It presents a suitable way to control solar based systems such as solar thermal plants. FLC is a control system where a mathematical system analyzes analog inputs related to logical variables ranged between 0 and 1. In fact, FLC is based on a control algorithm of linguistic control strategy Depending on a defined set of rules. The consequent results from a linear input-output relation in a region of the state space. The main blocks in the fuzzy logic controller are (Figure 4):

-Fuzzification.

-Rule base.

-Defuzzification.

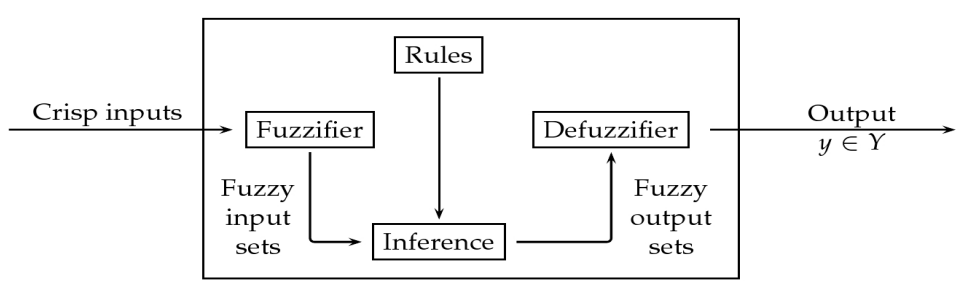

Figure 4. Fuzzy controller process blocks. 


\subsection{Fuzzification}

It consists of converting numerical input variables into linguistic variables. In this step we identify which state variables will be considered as input variables in the fuzzy logic controller. Each piece of input data is converted to degrees of membership by a lookup in a number of membership functions.

The input variables in our system are PV cells temperature and water temperature whose are the main impactful factors on PV/T field efficiency and RO unit performance. PV cells temperature is considered hot when it surpasses $40^{\circ} \mathrm{C}$. From this value we start to think about cooling PV/T cells by increasing the fluid flow rate in order to ameliorate the electric efficiency of the PV/T field. Concerning the feed water temperature, from $30^{\circ} \mathrm{C}$, water temperature is considered hot even if the operating temperature limit is $45^{\circ} \mathrm{C}$ in order to prevent any risk of exceeding the operating temperature limit.

The chosen Fuzzifier type is triangular (Figure 5 and Figure 6).

\subsection{Rule Base}

Rules are presented in "If... then" format. The collect of rules is named "rule base". The computer executes the rules and determines the control signal corresponding to the considered measured inputs. The following table shows the fuzzy controller rule base (Table 1 ).

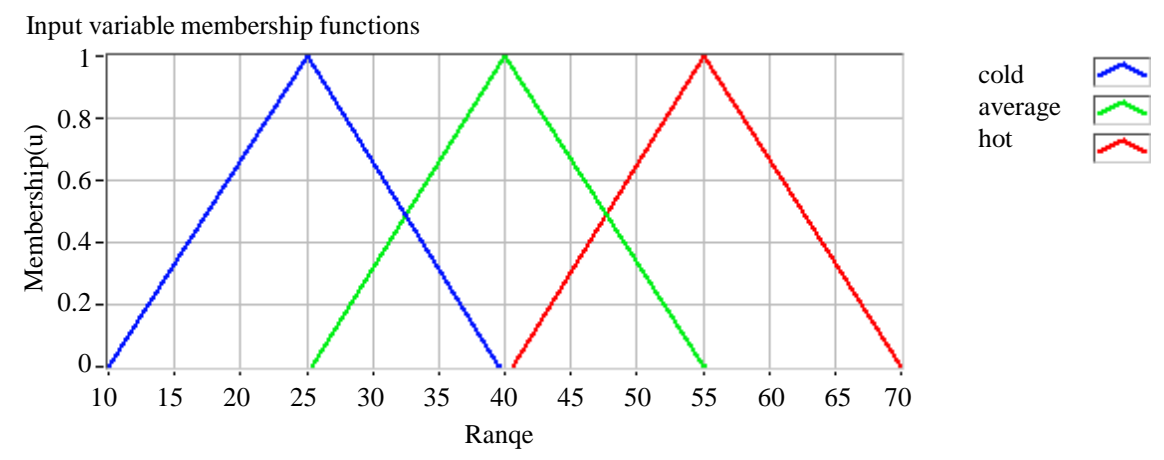

Figure 5. Membership function of PV cell temperature.

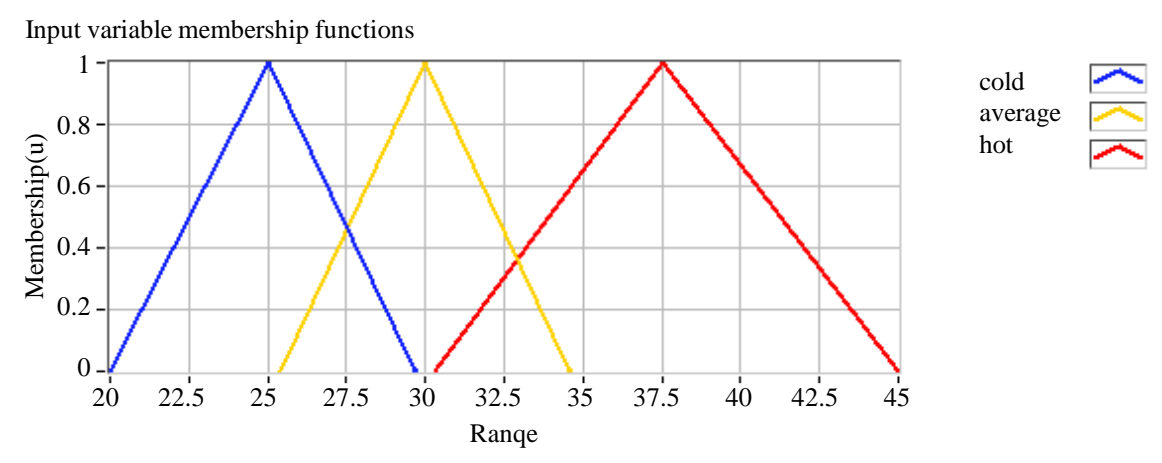

Figure 6. Membership function of tanked water temperature.

Table 1. Rule base.

\begin{tabular}{cccc}
\hline & & & PV/T cell temperature \\
Tanked water temperature & Cold & Average & Hot \\
\cline { 2 - 4 } Cold & Very low & Low & Average \\
Average & Low & Average & High \\
Hot & Average & High & Very high \\
\hline
\end{tabular}


In fact, the control balances between cooling the PV/T cells to promote electric energy production and heating feed water temperature to ameliorate the RO system recovery rate. The relationship between the Fuzzy system inputs and output is represented by Figure 7.

\subsection{Defuzzification}

Defuzzification consists of combining and converting all the actions into an output signal, this signal presents the control output signal attributed to the system. The considered method of Defuzzification is "center of gravity". The controlled signal in our system is fluid flow rate. The membership function distribution of controlled signal is presented by the following figure (Figure 8).

\section{Results and Discussion}

\subsection{Energetic Gain}

Modeled system and the developed fuzzy controller are tested for the considered distribution of solar radiation and ambient temperature shown in Figure 9. Simulation was performed using LABVIEW.

Table 2 represents the considered system parameters during the simulation.

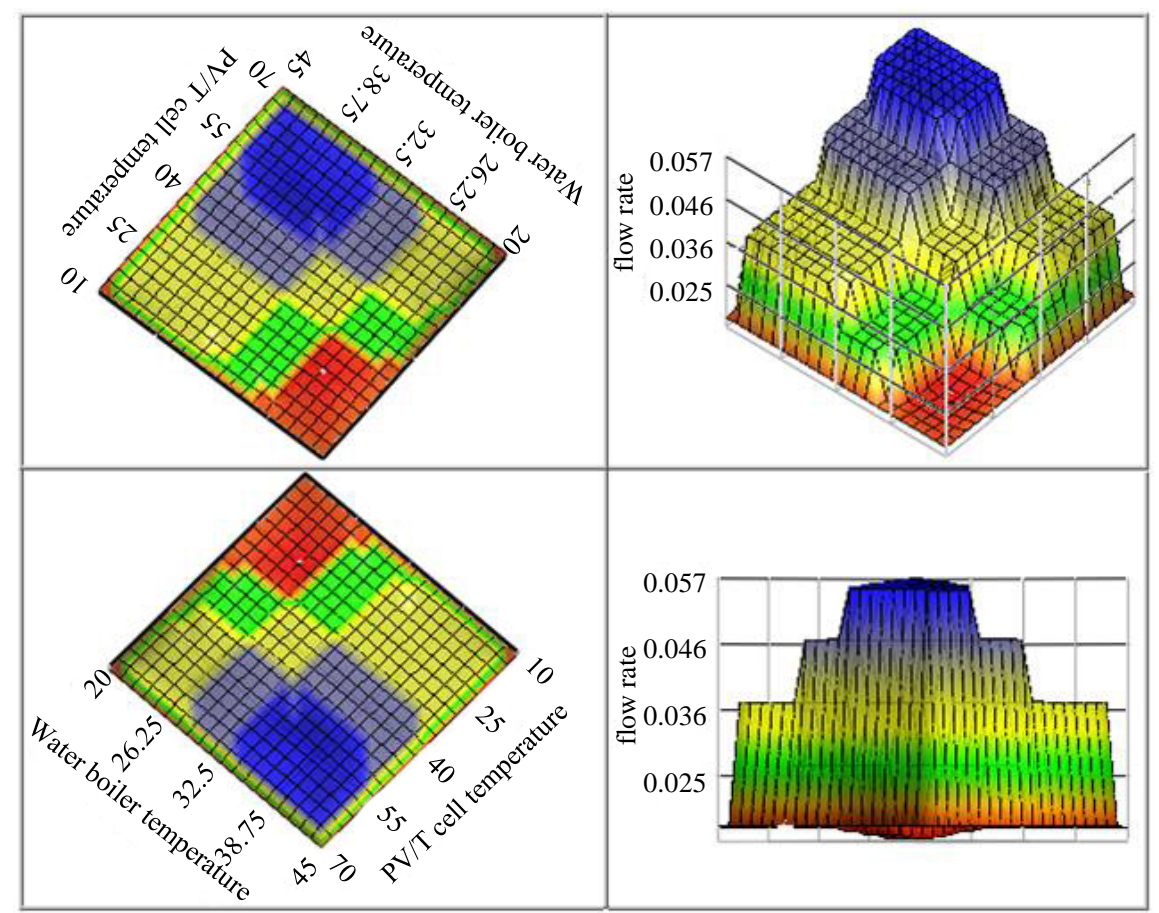

Figure 7. Inputs/output relationship.

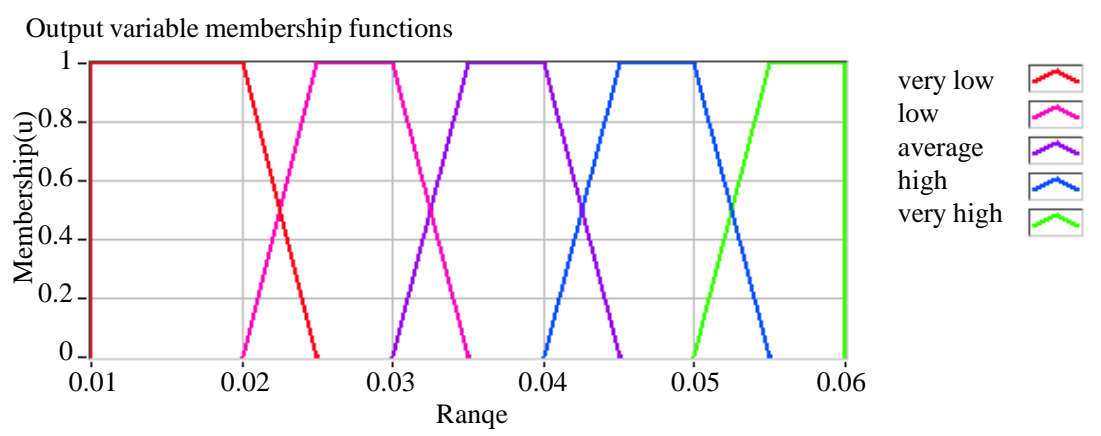

Figure 8. Membership function of the fluid flow rate. 

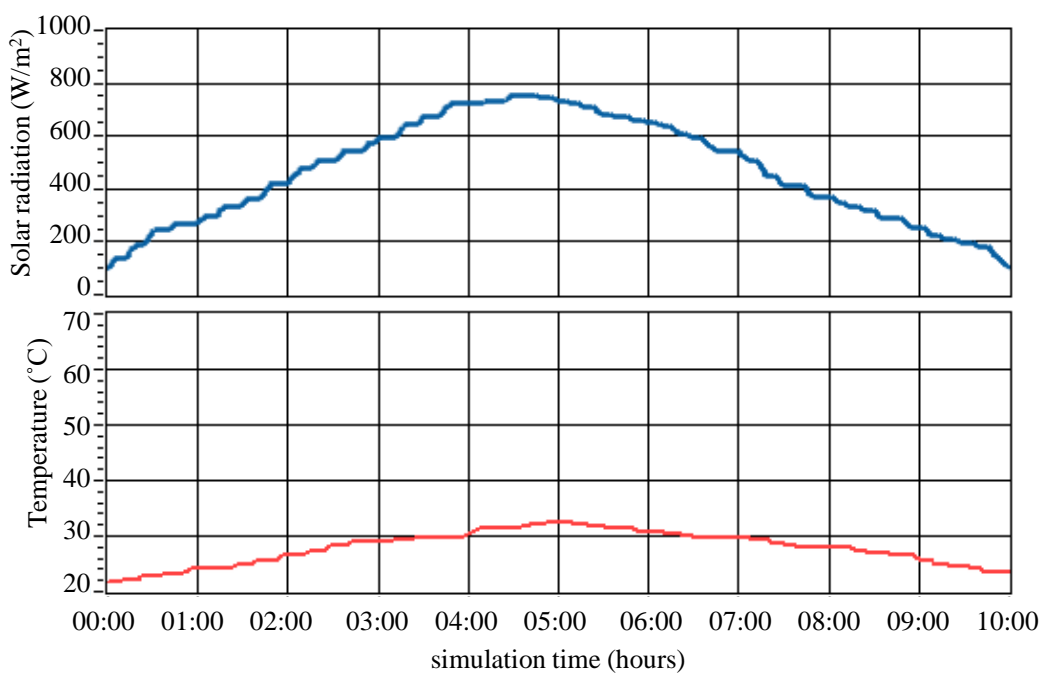

Figure 9. Solar radiation and ambient temperature distribution.

\section{Table 2. Data used for simulation.}

\begin{tabular}{|c|c|c|c|}
\hline PV/T layers & Parameters & Symbols & Value \\
\hline \multirow[t]{7}{*}{ Glass cover } & Aperture area $\left(\mathrm{m}^{2}\right)$ & $A$ & 2 \\
\hline & Density $\left(\mathrm{kg} / \mathrm{m}^{3}\right)$ & $\rho_{g}$ & 2200 \\
\hline & Emissivity & $\varepsilon_{g}$ & 0.88 \\
\hline & Extinction coefficient (/m) & $\Lambda$ & 26 \\
\hline & Refractive index & $R_{g}$ & 1.5 \\
\hline & Specific heat (J/kg) & $C_{g}$ & 670 \\
\hline & Thickness (m) & $\delta_{g}$ & 0.004 \\
\hline \multirow[t]{3}{*}{ PV plate } & Packing factor & $p$ & 0.804 \\
\hline & Temperature coefficient (\%) & $\beta_{r}$ & 0.4 \\
\hline & Reference cell efficiency (\%) & $\eta_{r}$ & 15 \\
\hline \multirow[t]{5}{*}{ Absorber plate } & Absorptance of collector (\%) & $\alpha_{c}$ & 95 \\
\hline & Density of plate $\left(\mathrm{kg} / \mathrm{m}^{3}\right)$ & $\rho_{c}$ & 2702 \\
\hline & Emissivity & $\varepsilon_{c}$ & 7 \\
\hline & Thickness of plate (m) & $\delta_{c}$ & 0.0002 \\
\hline & Thermal conductivity (W/mK) & K & 310 \\
\hline \multirow[t]{7}{*}{ Tube } & Diameter of tube (m) & $D_{o}$ & 0.00953 \\
\hline & Density of tube $\left(\mathrm{kg} / \mathrm{m}^{3}\right)$ & $\rho_{t}$ & 2702 \\
\hline & Length of tube (m) & $L$ & 1.916 \\
\hline & Number of tubes & $N$ & 10 \\
\hline & Specific heat of tube $(\mathrm{J} / \mathrm{kgK})$ & $C_{t}$ & 903 \\
\hline & Spacing of tubes (m) & $W$ & 0.1 \\
\hline & Thickness of tube (m) & $\delta_{t}$ & 0.0009 \\
\hline \multirow[t]{3}{*}{ Insulation } & Density of insulation $\left(\mathrm{kg} / \mathrm{m}^{3}\right)$ & $\rho_{i}$ & 20 \\
\hline & Specific heatofinsulation (J/kgK) & $C_{i}$ & 670 \\
\hline & Thermal conductivity (W/mK) & $k_{i}$ & 0.034 \\
\hline
\end{tabular}


The controlled system is used to desalinate seawater. The salinity of the considered seawater is $36000 \mathrm{ppm}$. It is acquired that potable water salinity should be lower than $500 \mathrm{ppm}$. RO model simulation shows that feed water temperature should be kept lower than $45^{\circ} \mathrm{C}$ in order to guarantee an acceptable permeate salinity (Figure 10).

The simulation illustrates the advantages of the developed fuzzy controller. The employed fuzzy controller balances between the improvement of PV/T field efficiency and the amelioration of the reverse osmosis unit performance. Temperature evolution of each system blocks is shown in Figure 11. In fact, it is shown that water temperature in the boiler is maintained lower than the maximum temperature acceptable to protect the reverse osmosis membrane and to guarantee satisfactory water salinity (Figure 11). In addition, PV/T cell temperature varies with solar radiation and ambient temperature changes. The maximum temperature exceeded by PV/T cell is $48^{\circ} \mathrm{C}$. It is clear that fluid circulation prevents the overheating of solar cells even for important solar radiation and elevated ambient temperature.

$\mathrm{PV} / \mathrm{T}$ field electric efficiency is shown in Figure 12. During the simulation time, electric efficiency is kept near to the reference efficiency. Also, PV/T electrical efficiency is kept higher than the electrical efficiency of a conventional PV panel in the same conditions (Figure 13).

An improvement in the recovery rate of the reverse osmosis unit is also mentioned. The simulation shows that the recovery rate exceeds $47 \%$. This presents a gain of $12 \%$ compared to standards conditions where the recovery rate is equal to $35 \%$ with a feed water temperature equal to $20^{\circ} \mathrm{C}$ (Figure 14). Consequently, the consumed power will be reduced as well as the quantity of pumped water.

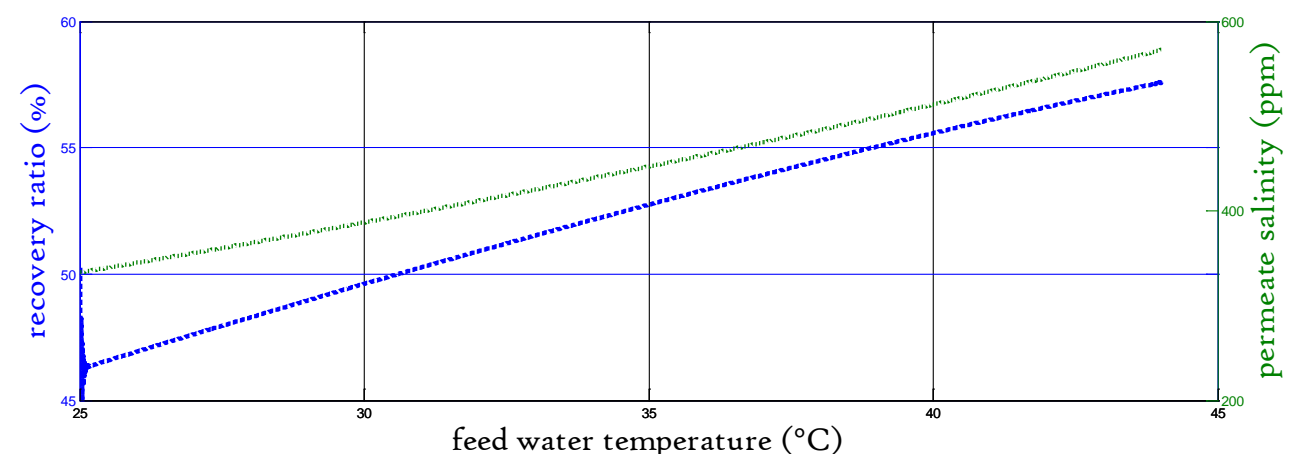

Figure 10. Permeate salinity evolution (for 36000 ppm seawater salinity).

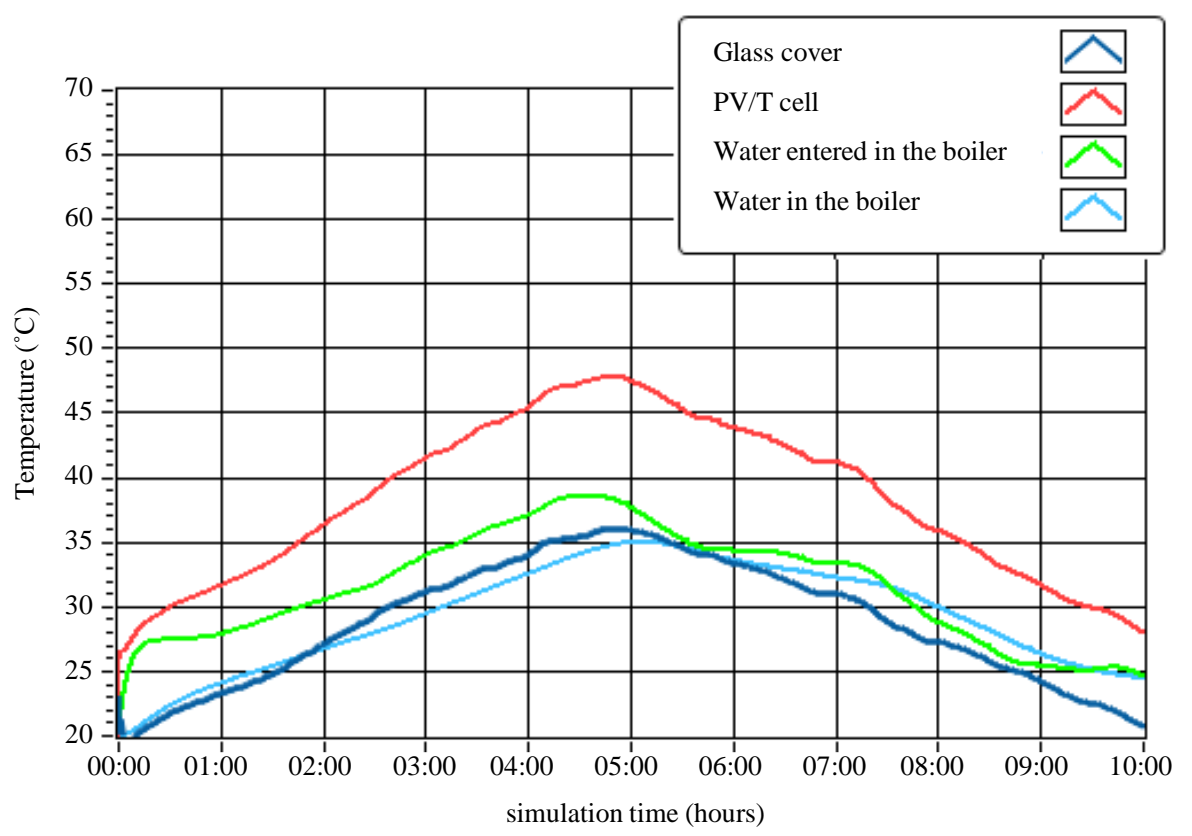

Figure 11. Different calculated temperatures. 


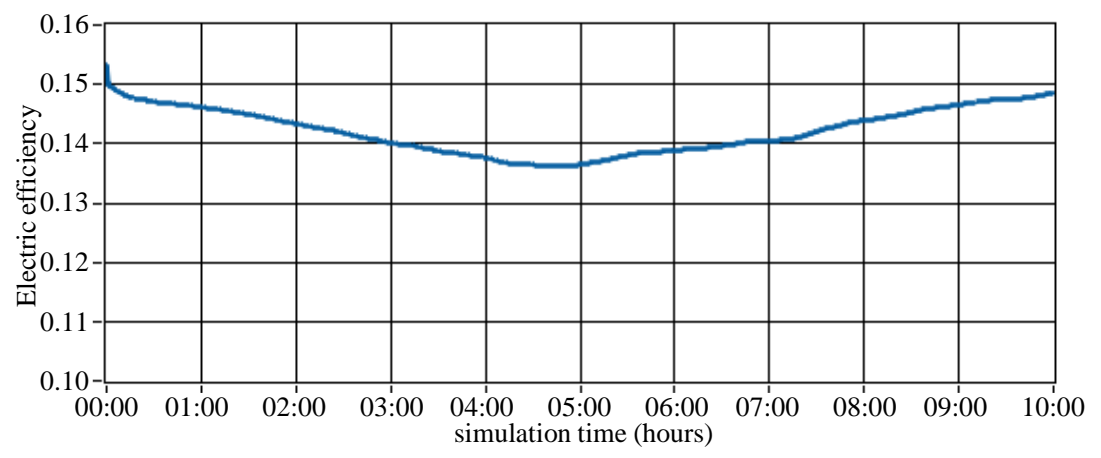

Figure 12. PV/T electric efficiency.

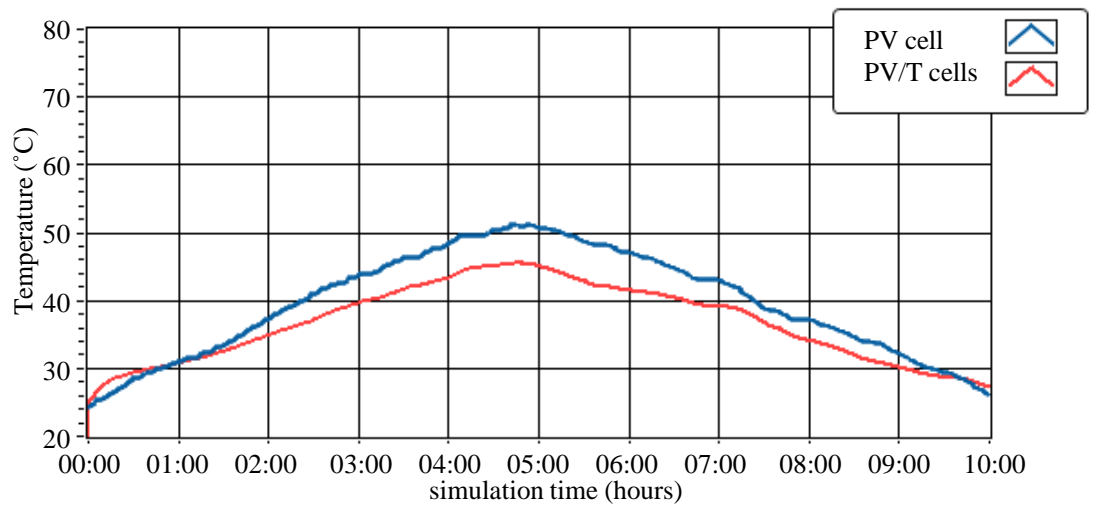

Figure 13. PV/T and PV cells temperatures.

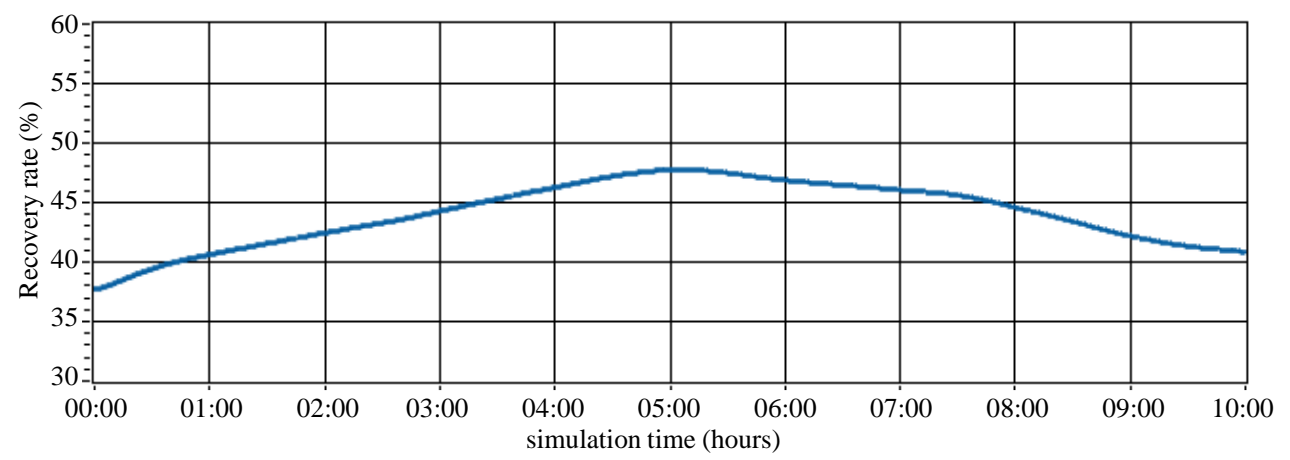

Figure 14. Reverse Osmosis unit recovery rate evolution.

Fluid mass flow rate varies according to the state space variables and the system states (PV/T cell temperature, and boiler water temperature), in order to optimize the plant yield as shown in Figure 15.

Moreover, the produced permeate salinity is kept lower than the acceptable limit (500 ppm) (Figure 16).

\subsection{Economic Benefit}

The method of the life cycle cost (LCC) is used to evaluate the financial viability of the system compared to a similar plant supplied by photovoltaic panels. It is considered that the two compared plants serve to cover a daily water need equal to $227 \mathrm{~m}^{3}$. The total cost throughout its life including planning, design, acquisition and support costs and any other costs directly attributable to owning or using the asset. Life Cycle Costing adds all the costs of alternatives over their life period and enables an evaluation on a common basis for the period of interest (usually using discounted costs). This enables decisions on acquisition, maintenance, refurbishment or disposal to be made in the light of full cost implications (Table 3 and Table 4). 


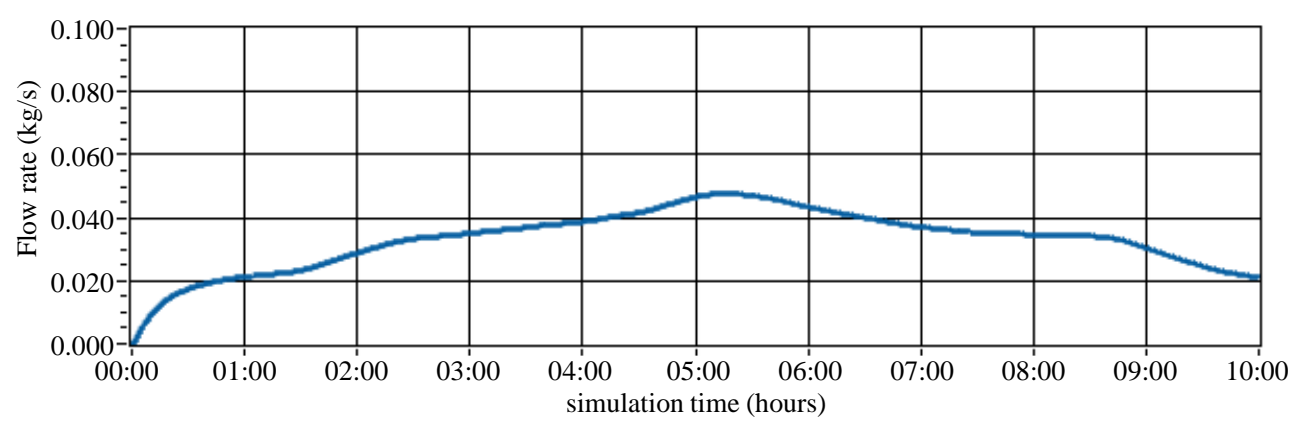

Figure 15. Fluid flow rate variation.

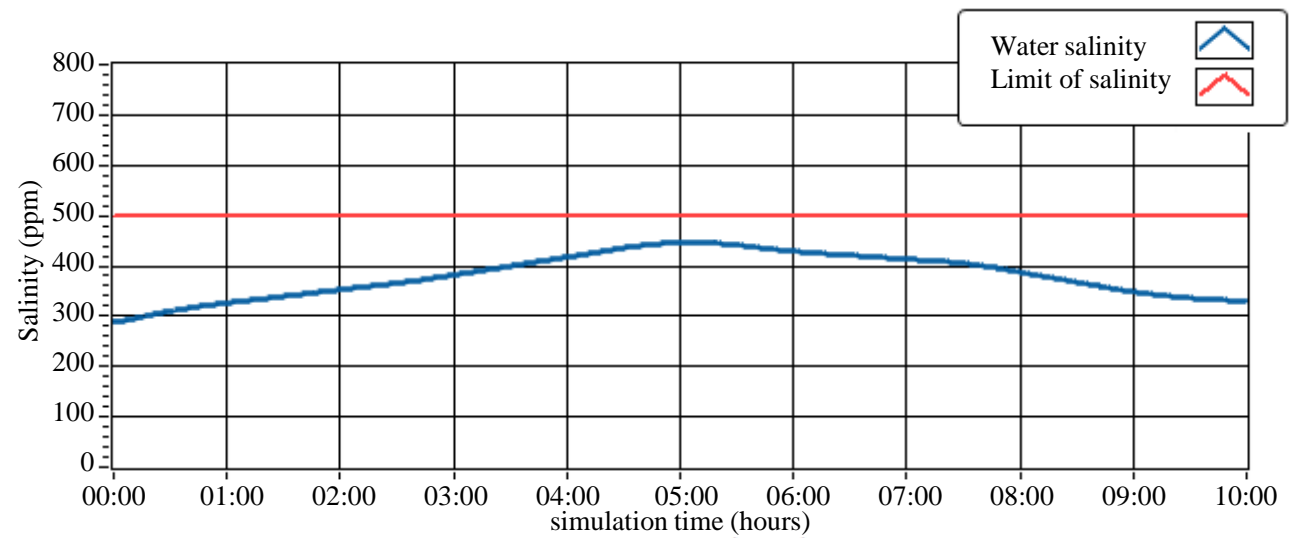

Figure 16. Permeate salinity.

Table 3. PV/T based desalination plant cost analysis using LCC method.

\begin{tabular}{|c|c|c|c|c|c|}
\hline Product code & Description & Amount & Unit price (\$) & Total (\$) & \\
\hline PVT-01 & PV/T panel (200 w) & 440 & 455 & 200200 & \\
\hline Inverter & 10000 VA, 48 V inverter charger & 7 & 6550 & 45850 & \\
\hline Solar battery & Solar batteries 12 V 100 ah & 196 & 84.32 & 16526.72 & \\
\hline DC-AC & DC-AC cables and accessories & 110 & 300 & 33000 & \\
\hline BS & boiler single serpentine & 1 & 48598 & 48598 & \\
\hline PMP-01 & Circulating pump & 55 & 274 & 15070 & \\
\hline PMP-02 & water pumping pump & 1 & 3359 & 3359 & \\
\hline FT & fluid tank & 55 & 25 & 1375 & \\
\hline \multirow[t]{4}{*}{ RO membrane } & reverse osmosis unit & 1 & 234972 & 234972 & \\
\hline & & & & Plant components cost & 598950.72 \\
\hline & & & & Installation cost & 149737.68 \\
\hline & & & & Initial cost & 748688.4 \\
\hline Maintenance cost & & & & 190430 & \\
\hline \multicolumn{6}{|l|}{ Replacement cost } \\
\hline Inverter & 28794 & & & & \\
\hline Water pumping pump & 2109.5 & & & & \\
\hline Batteries & 10379 & & & & \\
\hline RO unit & 450710 & & & & \\
\hline \multirow[t]{2}{*}{ Total of replacement cost (\$) } & 491992.5 & & & & \\
\hline & & & & TOTAL PLANT COST (\$) & 1431110.9 \\
\hline
\end{tabular}


Table 4. PV based desalination plant cost analysis using LCC method.

\begin{tabular}{|c|c|c|c|c|c|}
\hline Product code & Description & Amount & Unit price (\$) & Total (\$) & \\
\hline PVT-01 & PV panel (220 w) & 522 & 528.42 & 275835.24 & \\
\hline SMA inverter & $\begin{array}{l}10000 \mathrm{VA}, 48 \mathrm{~V} \\
\text { inverter charger }\end{array}$ & 9 & 6550 & 58950 & \\
\hline Solar battery & $\begin{array}{l}\text { Batteries } 12 \text { V } 100 \text { ah for } \\
\text { Solar Power System }\end{array}$ & 244 & 84.32 & 20574.08 & \\
\hline DC-AC & $\begin{array}{l}\text { DC-AC cables } \\
\text { and accessories }\end{array}$ & 136 & 300 & 40800 & \\
\hline PMP-02 & Water pumping pump & 1 & 3359 & 3359 & \\
\hline RO membrane & Reverse osmosis unit & 1 & 234972 & 234972 & \\
\hline \multirow[t]{3}{*}{ Plant components cost } & & & & Plant components cost & 634490 \\
\hline & & & & Installation cost & 158623 \\
\hline & & & & Initial cost & 793113 \\
\hline Maintenance cost & & & & 193670 & \\
\hline \multicolumn{6}{|l|}{ Replacement cost } \\
\hline Inverter & 37021 & & & & \\
\hline Water pumping pump & 2109.5 & & & & \\
\hline Batteries & 12921 & & & & \\
\hline RO unit & 450710 & & & & \\
\hline \multirow[t]{2}{*}{ Total of replacement cost (\$) } & 502761.5 & & & & \\
\hline & & & & TOTAL PLANT COST (\$) & 1489544 \\
\hline
\end{tabular}

Table 5. Plant performances.

\begin{tabular}{ccc}
\hline Compared criteria & PV/T & PV \\
\hline Daily water production $\left(\mathrm{m}^{3}\right)$ & 227 & 227 \\
Field surface $\left(\mathrm{m}^{2}\right)$ & 600 & 860 \\
Plant cost $(\$)$ & 1431110.9 & 1457839 \\
Cells efficiency (\%) & $13.71 \%$ & $11.96 \%$ \\
Energy consumption (KWh/day) & 705 & 871.5 \\
\hline
\end{tabular}

Compared to the technology using PV based plant, the proposed concept and the developed control strategy reduce the reserved space for the implementation next to the initial cost which will be reduced (Table 5). Indeed, $\mathrm{PV} / \mathrm{T}$ technology can refer PV collectors to power reverse osmosis desalination systems. Additionally, even if the $\mathrm{PV} / \mathrm{T}$ based system is more complicated especially with more components and blocks in the installation like the heating water system, plant cost and water production cost still lower than PV system. Moreover, with an optimum control strategy the plant performance and water production cost will be reduced more.

\section{Conclusions}

Architecture of a PV/T based reverse osmosis desalination plant presented and system functioning is detailed. The system description shows how to make use of PV/T technology to improve reverse osmosis desalination unit profitability. Dynamic model for the conceived system is developed in order to evaluate the system performances. Indeed, the system is subdivided into different subsystems and a state space model presentation is considered to perform the simulation using LABVIEW.

A Fuzzy Logic Controller is designed to improve the system productivity. The simulation shows an improvement of the plant performances (PV/T field efficiency and RO unit recovery). Indeed, the designed Fuzzy Logic Controller ensures an energy saving by reducing the consumed energy in the desalination process per cubic meter, and improving the PV/T field electric efficiency. Furthermore, RO membrane is protected by maintaining the feed water temperature lower than feed water limit temperature of reverse osmosis membrane, and consequently, the 
quantity of rejected salts is reduced which presents an ecologic advantage.

Additionally, the developed economic analysis shows that an important benefit is afforded by using PV/T technology to power reverse osmosis desalination systems. In fact, the comparison shows that for the same system capacity, the plant initial cost for PV/T based system is lower than for PV based system. Consequently, water production cost is reduced.

\section{Acknowledgements}

We express thanks to the School of Natural Resources Engineering and Management at German Jordanian University for the support.

\section{References}

[1] UNESCO (2003) Water for People Water for Life the United Nations World Water Development Report. Berghahn Books.

[2] Riffel, D.B. and Carvalho, P.C.M. (2009) Small-Scale Photovoltaic-Powered Reverse Osmosis Plant without Batteries: Design and Simulation. Desalination, 247, 378-389. http://dx.doi.org/10.1016/j.desal.2008.07.019

[3] Eltawil, M.A., Zhao, Z.M. and Yuan, L.Q. (2009) A Review of Renewable Energy Technologies Integrated with Desalination Systems. Renewable and Sustainable Energy Reviews, 13, 2245-2262. http://dx.doi.org/10.1016/j.rser.2009.06.011

[4] El-Nashar, A.M. (2001) The Economic Feasibility of Small Solar MED Seawater Desalination Plants for Remote Arid Areas. Desalination, 134, 173-186. http://dx.doi.org/10.1016/S0011-9164(01)00124-2

[5] Hou, S.B., Zhang, Z.J., Huang, Z.Z. and Xie, A.X. (2008) Performance Optimization of Solar Multi Flash Desalination Process Using Pinch Technology. Desalination, 220, 524-530. http://dx.doi.org/10.1016/j.desal.2007.01.052

[6] Qtaishat, M.R. and Banat, F. (2013) Desalination by Solar Powered Membrane Distillation Systems. Desalination, 308, 186-197. http://dx.doi.org/10.1016/j.desal.2012.01.021

[7] de Carvalho, P.C.M. and Riffel, D.B. (2004) The Brazilian Experience with a Photovoltaic Powered Reverse Osmosis Plant. Progress in Photovoltaics Research and Applications, 12, 373-385. http://dx.doi.org/10.1002/pip.543

[8] Bilton, A.M., Wiesman, R., Arif, A.F.M., Zubair, S.M. and Dubowsky, S. (2011) On the Feasibility of CommunityScale Photovoltaic-Powered Reverse Osmosis Desalination Systems for Remote Locations. Renewable Energy, 36, 3246-3256. http://dx.doi.org/10.1016/j.renene.2011.03.040

[9] Qiblawey, H., Banat, F. and Al-Nasser, Q. (2011) Performance of Reverse Osmosis Pilot Plant Powered by Photovoltaic in Jordan. Renewable Energy, 36, 3452-3460. http://dx.doi.org/10.1016/j.renene.2011.05.026

[10] Kima, S.J., Lee, Y.G., Oh, S., Lee, Y.S., Kim, Y.M., Jeon, M.G., Lee, S., Kim, I.S. and Kim, J.H. (2009) Energy Saving Methodology for the SWRO Desalination Process: Control of Operating Temperature and Pressure. Desalination, 247, 260-270. http://dx.doi.org/10.1016/j.desal.2008.12.006

[11] Al-Mutaz, I.S. and Al-Ghunaimi, M.A. (2001) Performance of Reverse Osmosis Units at High Temperatures. Proceedings of the IDA World Congress on Desalination and Water Reuse, Bahrain, 26-31 October 2001.

[12] Goosen, M.F.A., Sablani, S.S., Al-Maskari, S.S., Al-Belushi, R.H. and Wilf, M. (2002) Effect of Feed Temperature on Permeate Flux and Mass Transfer Coefficient in Spiral-Wound Reverse Osmosis Systems. Desalination, 144, $367-372$. http://dx.doi.org/10.1016/S0011-9164(02)00345-4

[13] Kelley, L.C. and Dubowsky, S. (2013) Thermal Control to Maximize Photovoltaic Powered Reverse Osmosis Desalination Systems Productivity. Desalination, 314, 10-19. http://dx.doi.org/10.1016/j.desal.2012.11.036

[14] Bambrook, S.M. and Sproul, A.B. (2012) Maximising the Energy Output of a PVT Air System. Solar Energy, 86, 1857-1871. http://dx.doi.org/10.1016/j.solener.2012.02.038

[15] Ammous, M. and Chaabene, M. (2014) PV/T Based Desalination Plant: Concept and Assessment. Proceedings of the Fifth International Renewable Energy Congress IREC, Hammamet, 25-27 March 2014.

[16] Bhattarai, S., Oh, J.-H., Euh, S.-H., Kafle, G.K. and Kim, D.H. (2012) Simulation and Model Validation of Sheet and Tube Type Photovoltaic Thermal Solar System and Conventional Solar Collecting System in Transient States. Solar Energy Materials \& Solar Cells, 103, 184-193. http://dx.doi.org/10.1016/j.solmat.2012.04.017

[17] Ammous, M. and Chaabene, M. (2015) Multi Criteria Sizing Approach for Photovoltaic Thermal Collectors Supplying Desalination Plant. Energy Conversion and Management, 94, 365-376. http://dx.doi.org/10.1016/j.enconman.2015.02.004

[18] Priya, G.S.K., Thakare, M.S., Ghosh, P.C. and Bandyopadhyay, S. (2013) Sizing of Standalone Photovoltaic Thermal 
(PVT) Systems Using Design Space Approach. Solar Energy, 97, 48-57. http://dx.doi.org/10.1016/j.solener.2013.08.003

[19] Sandnes, B. and Rekstad, J. (2002) A Photovoltaic/Thermal (PV/T) Collector with a Polymer Absorber Plate. Experimental Study and Analytical Model. Solar Energy, 72, 63-73.

[20] Bakar, M.N.A., Othman, M., Din, M.H. and Manaf, N.A. (2014) Design Concept and Mathematical Model of a BiFluid Photovoltaic/Thermal (PV/T) Solar Collector. Renewable Energy, 67, 153-164. http://dx.doi.org/10.1016/j.renene.2013.11.052

[21] Nagano, K., Mochida, T., Shimakura, K., Murashita, K. and Takeda, S. (2003) Development of Thermal-Photovoltaic Hybrid Exterior Wallboards Incorporating PV Cells in and Their Winter Performances. Solar Energy Materials \& Solar Cells, 77, 265-282. http://dx.doi.org/10.1016/S0927-0248(02)00348-3

[22] Ammar, M.B., Chaabene, M. and Chtourou, Z. (2013) Artificial Neural Network Based Control for PV/T Panel to Track Optimum Thermal and Electrical Power. Energy Conversion and Management, 65, 372-380. http://dx.doi.org/10.1016/j.enconman.2012.08.003

[23] Ali, M.A., Ajbar, A., Ali, E. and Alhumaizi, K. (2010) Robust Model-Based Control of a Tubular Reverse-Osmosis Desalination Unit. Desalination, 255, 129-136. http://dx.doi.org/10.1016/j.desal.2010.01.003

[24] Salim, Ohri, J. and Naveen (2013) Speed Control of DC Motor Using Fuzzy Logic Based on LabVIEW. International Journal of Scientific and Research Publications, 3.

[25] Lu, J.-J., Huang, H.-H. and Chou, H.-P. (2015) Evaluation of an FPGA-Based Fuzzy Logic Control of Feed-Water for ABWR under Automatic Power Regulating. Progress in Nuclear Energy, 79, 22-31. http://dx.doi.org/10.1016/j.pnucene.2014.10.010

[26] Lygouras, J.N., Kodogiannis, V.S., Pachidis, T., Tarchanidis, K.N. and Koukourlis, C.S. (2008) Variable Structure TITO Fuzzy-Logic Controller Implementation for a Solar Air-Conditioning System. Applied Energy, 85, 190-203. http://dx.doi.org/10.1016/j.apenergy.2007.07.001

[27] Altas, I.H. and Sharaf, A.M. (2008) A Novel Maximum Power Fuzzy Logic Controller for Photovoltaic Solar Energy Systems. Renewable Energy, 33, 388-399. http://dx.doi.org/10.1016/j.renene.2007.03.002

[28] Chow, T.T., Pei, G., Fong, K.F., Lin, Z., Chan, A.L.S. and Ji, J. (2009) Energy and Energy Analysis of PhotovoltaicThermal Collector with and without Glasscover. Applied Energy, 86, 310-316.

[29] Vince, F., Marechal, F., Aoustin, E. and Bréant, P. (2008) Multi-Objective Optimization of RO Desalination Plants. Desalination, 222, 96-118. http://dx.doi.org/10.1016/j.desal.2007.02.064

[30] Çomaklı, K., Çakır, U., Kaya, M. and Bakirci, K. (2012) The Relation of Collector and Storage Tank Size in Solar Heating Systems. Energy Conversion and Management, 63, 112-117. http://dx.doi.org/10.1016/j.enconman.2012.01.031

[31] Jallouli, R. and Krichen, L. (2012) Sizing, Techno-Economic and Generation Management Analysis of a Standalone Photovoltaic Power Unit including Storage Devices. Energy, 40, 196-209. http://dx.doi.org/10.1016/j.energy.2012.02.004

[32] Al-Karaghouli, A. and Kazmerski, L.L. (2013) Energy Consumption and Water Production Cost of Conventional and Renewable Energy Powered Desalination Processes. Renewable and Sustainable Energy Reviews, 24, 343-356. http://dx.doi.org/10.1016/j.rser.2012.12.064 